Bishop, P. Plate tectonics etc in Matthews, J.A. et al. (editors). 2012. The SAGE

Handbook of Environmental Change. London, Sage; Volume 1, pages 363-383

\title{
Chapter 17. \\ Plate Tectonics, Continental Drift, Vulcanism and Mountain Building
}

\author{
Paul Bishop \\ School of Geographical and Earth Sciences \\ University of Glasgow \\ Glasgow G12 8QQ \\ UK \\ paul.bishop.3@glasgow.ac.uk
}

\section{Introduction}

A locality's environment encompasses many elements and so the term "environment" may take many different meanings. This chapter examines the roles of 'deeper Earth' processes in determining an area's environment, and in that context "environment" means aspects of the environment that are (a) actively influenced by deeper Earth processes and/or (b) a passive response to those internal processes. The role of volcanic eruptions in directly modifying local environment is an example of the former effect - the eruption cloud can directly modify temperature regimes at the Earth's surface in areas distant from the eruption. The latter effect - the passive response to internal Earth processes - is expressed in the ways in which environment and environmental change are indirect consequences of those internal processes, as in the ways in which local environment reflects, for example, latitudinal position which itself is a function of the continental drift associated with plate tectonics. In that case, the deeper processes set the context for environment, and "environment" is thus taken to mean regional aspects of the environment, such as average annual temperature and rainfall, seasonal regimes such as the monsoon, and perhaps average wind speed and direction. These environmental conditions are a function of an area's latitude and continentality, its altitude and the altitude of adjacent areas, and atmospheric and ocean circulation (if relevant) at that locality. All of these factors are fundamentally controlled and modified by plate tectonics in that those tectonics affect continental drift, oceanic circulation, and mountain building with associated affects on atmospheric circulation. When deeper Earth processes directly influence the environment - that is, case (a) above - the effect is likely to be more specific and perhaps not persistent, as when a volcanic eruption causes a period of cooler temperatures that temporarily perturb the local average conditions and from which the temperatures then 'recover'.

This chapter presents the ways in which these controls and modifications operate, the timescales of their operations, and the magnitudes of the environmental changes for which they may be responsible. The timescales over which these factors 'drive' environmental change vary from years, in the case of volcanic eruptions, to millions of years in the case of continental drift. This range of time-scales notwithstanding, the common point in all these changes is that they are driven in one way or another from within the Earth, and not by the external forcing of mechanisms such as astronomical cycles (see Section III of this book). 
Bishop, P. Plate tectonics etc in Matthews, J.A. et al. (editors). 2012. The SAGE

Handbook of Environmental Change. London, Sage; Volume 1, pages 363-383

\section{Background}

Global climates

Regional climates, of the spatial extent that can be affected by the subject of this chapter, currently reflect latitudinal position, altitude, the temperature of offshore seas, distance from the sea (continentality), and location in relation to major high altitude topography that tends to deplete air masses of their moisture (the rain-shadow effect) (Houston and Hartley, 2003). Thus, arid regions such as the Atacama, the African deserts, and the arid interior of Australia are all located under the descending stable air of the subtropical high pressure belts (the descending arms of the Hadley cell), and areas in the interior of large landmasses, distant from oceanic sources of moisture, are likewise dry (e.g., the interiors of the Asian, Australian and African landmasses). Where high (or even moderate) topography lies in the path of moist air masses, rainfalls are high, but they are low downwind, in the rainshadow area (e.g., the dry interior of Asia inland of the Himalayan mountain front with its very high rainfalls). And finally, areas landward of warm ocean currents, whose higher temperatures enhance evaporation, may be moister than they otherwise would be (e.g., the warm Leeuwin Current enhances rainfall in southwest Western Australia, and the Gulf Stream (North Atlantic Drift) is an important factor in the higher rainfalls of the western British Isles). Cold currents are generally associated with arid areas to landward, such as the Namib desert adjacent to the cold Benguela Current, and the Atacama Desert onshore of the cold Peruvian Current (also called the Humboldt Current).

Aridity and cooling at regional to global scales are generally the principal types of environmental change in which large scale tectonic processes have been implicated as key drivers. Given that the principal source of moisture that falls as precipitation is evaporation from the oceans, cooler sea-surface temperatures have been widely implicated in global cooling and increased aridity throughout the Cenozoic (see below).

Isostasy and plate tectonics

In the absence of countervailing forces and in response to the density contrasts between the lithosphere (density $d$ of $2,700 \mathrm{~kg} \mathrm{~m}^{-3}$ ) and the underlying asthenosphere $\left(d=3,000 \mathrm{~kg} \mathrm{~m}^{-3}\right)$, the semi-rigid lithosphere, the outer 'skin' of the Earth, floats on the viscous and deformable asthenosphere (Summerfield 1991). This equilibrium floating of the lithosphere on the asthenosphere, according to the thickness and density of the lithosphere, embodies the principle of isostasy, the fundamental geophysical phenomenon underpinning the operation of plate tectonics. Heat from the Earth's interior drives plate tectonics, which comprise interactions of lithosphere and asthenosphere. Continental lithosphere is moved about the Earth's surface by a range of forces, including the drag at the base of the lithosphere exerted by the spreading arms of convection cells in the underlying viscous mantle, the gravitational sliding of plates away from the topographic highs of the mid-ocean ridges, and by the pull of lithosphere as it sinks back into the mantle at oceanic trenches.

Isostasy means that thicker crust floats higher - rock is uplifted - and so plate convergence, which generally results in crustal thickening, leads to rock uplift. That rock uplift does not necessarily correspond to surface uplift, however. This distinction between rock uplift and surface uplift is important in terms of the potential impacts of tectonics and environmental change: rock uplift means upwards movement of the crustal 
Bishop, P. Plate tectonics etc in Matthews, J.A. et al. (editors). 2012. The SAGE

Handbook of Environmental Change. London, Sage; Volume 1, pages 363-383

rock column outwards, away from the centre of the Earth. Such uplift corresponds to surface uplift (i.e. upward movement of the Earth's surface) to the extent that surface processes of weathering and erosion do not 'keep pace' with that rock uplift (Summerfield 1991; Burbank and Anderson 2001; Willett and Brandon 2002). Zero erosion of the uplifting rock column means that the surface is uplifted by the amount of rock uplift, whereas if the rate of surface processes is the same as the rate of rock uplift, there is no surface uplift. These concepts are important to understanding the interactions between the growth of topography and environmental change, to which the discussion returns below.

Plate tectonics have the potential to trigger environmental change at a locality as a result of:

- latitudinal movement of continents, and indirectly via changing the areas of contiguous landmass and hence continentality;

- changing oceanic circulation; and

- generating surface uplift that (a) cools the uplifted area, (b) changes global atmospheric circulation by projecting continental mass up into that atmospheric circulation, and/or (and more contentiously) (c) leads to changes in the nature and rate of surface processes, including rock weathering, with the potential for 'knock-on' effects for atmospheric composition and hence the temperature and moisture balance of the Earth's surface.

As we have already noted, plate tectonics may also trigger environmental change via volcanic eruptions that modify climate.

\section{Surface uplift}

Surface uplift will self-evidently result in environmental changes because air temperature decreases with increasing altitude according to the environmental lapse rate (defined by the United Nations' International Civil Aviation Organization as $6.49^{\circ} \mathrm{C}$ per $1,000 \mathrm{~m})$. That cooling means that air masses cool when they are forced upwards by a mountain front, generating precipitation. Some of the highest rainfalls on Earth are associated with steep mountain front topography lying in the path of moist air masses, such as in Taiwan (annual rainfalls of $5 \mathrm{~m}$ in the Central Range of Taiwan and with very high intensity rainfall during typhoons [Lin 2000]), 11-12 $\mathrm{m}$ in the foothills of the Himalayas around Cherrapunji, the supposed 'wettest place on Earth', and an astonishing $15 \mathrm{~m}$ at the crest of the Southern Alps [Tippett and Hovius 2000]).

The changing environments associated with surface uplift (i.e., cooling and increased precipitation) is reflected in vegetation, and so Early Tertiary uplift of NW Britain has been inferred from palaeovegetation proxies and interpreted in terms of domal surface uplift associated with magma injection in the British Tertiary Igneous Province during a major period of regional igneous activity associated with the Iceland hotspot (Jolley 1997). The lithospheric thickening associated with the convergence of the Nazca and South American plates explains, in part at least, the uplift of the Andes (Lamb and Davis 2003). That uplift has likewise been inferred from palaeobotanical data, as well as from the uplift history of erosion surfaces and from estimates of crustal shortening associated with plate convergence (Gregory-Wodzicki 2000; Hartley 2003).

The causal association between lithospheric thickening and rock uplift is a manifestation of the principle of isostasy that thicker lithosphere 'floats' higher (Figure 
Bishop, P. Plate tectonics etc in Matthews, J.A. et al. (editors). 2012. The SAGE

Handbook of Environmental Change. London, Sage; Volume 1, pages 363-383

1). Thus, convergence rates of $38.5 \pm 3 \mathrm{~mm} \mathrm{a}^{-1}$ for the Southern Alps (translating into a rate of $\sim 11 \mathrm{~mm} \mathrm{a}^{-1}$ normal to the Alpine Fault - Tippett and Hovius 2000) and $\sim 70 \mathrm{~mm}$

$\mathrm{a}^{-1}$ for Taiwan (Lin 2000) translate into rates of rock uplift of 5-10 $\mathrm{mm} \mathrm{a}^{-1}$ and higher. Surface uplift may also reflect thermal updoming (i.e., a thermal isostatic effect). As we have seen, surface uplift means that surface processes (denudation) cannot match the amount by which rock at the Earth's surface has been uplifted isostatically. In the case of the Andes, Lamb and Davis (2003) have proposed a novel relationship between rock uplift, surface processes and the development of the Atacama Desert. They argued that the uplift of the Andes is in part an outcome of the development of the Atacama Desert, and not the reverse relationship, as has been invoked, as we see below, in the rainshadow effect hypothesis for the origin of the Atacama Desert. Lamb and Davis (2003) argued that the hyperaridity of the western seaboard of South America, reflecting the cold offshore current and the region's sub-tropical location under stable subsiding air, means that sediment supply to the offshore is extremely low to non-existent. That lack of sediment means in turn that that subduction of the Nazca Plate is not lubricated by sediment, leading to high shear stresses in the over-riding South American plate, which support the high Andes (Lamb and Davis 2003). In other words, the causal links between plate tectonics and environmental change may be reversed, such that the climate 'drives' the tectonics or rock uplift. This conceptual advance is one of the most exciting to have emerged in the last 20 years, but before turning to it, we examine ways in which plate tectonics has driven environmental change in ways that are more complex than the relatively simple effect of uplift leading to environmental change.

\section{Latitudinal movement of continents}

Continental movements about the Earth's surface, coupled with the latitudinal zonation of climates, may mean that continents pass through different climatic zones over time. Antarctica has resided in southern polar latitudes for the last $250 \mathrm{Ma}$ at least (Dalziel 1997; Veevers et al. 1991) but has not always been hyper-arid and cold (meaning that lack of plate motion does not necessarily mean lack of environmental change).

Australia rifted away from Antarctica c.45 Ma (Weissel et al. 1977) and its subsequent rate of northward motion is among the fastest currently on the Earth's surface (at 6-7 cm $\mathrm{a}^{-1}$ for the last $30 \mathrm{Ma}$ at least - Knesel et al. 2008). Such northward motion would be expected to have taken the continent through different climatic zones but such an explanation for the Neogene aridification of Australia is only partial, for it neglects the fact that ocean currents and atmospheric circulation also change with the changing global disposition of the continents, requiring a much more subtle interpretation. This subtlety is exemplified in relation to aridification of the Southern Hemisphere throughout the Tertiary, to which we now turn.

The post-Paleocene climate history of the Southern Hemisphere, and indeed of the whole Earth, has been one of essentially continuous cooling with short periods of reversal of that cooling trend (Figure 2). A major factor in the climate history of Australia, one of the major Southern Hemisphere landmasses and a nicely illustrative case study here, has been that cooling, which led to progressive - almost relentless aridification, interspersed with short periods of moister climates (see summaries by Martin (2006) and Fujioka and Chappell (2010)). Australia's 'modern' aridity reflects several factors, including its location under the stable, sub-tropical high pressure air 
Bishop, P. Plate tectonics etc in Matthews, J.A. et al. (editors). 2012. The SAGE

Handbook of Environmental Change. London, Sage; Volume 1, pages 363-383

masses of the subsiding arm of the Hadley Cell, the distance from the oceans of its arid interior (continentality), and the rain-shadow effect of the east Australian highlands for much of the precipitation coming from the east. Bowler (1982) was probably the first to note the temptation to attribute the Neogene aridification of Australia to its northward drift into the sub-tropical high pressure belts and, equally, that such an interpretation is superficial. Bowler (1982) argued that it is more likely that these high pressure belts 'overtook' Australia from the south (Figure 3), as atmospheric and oceanic circulation intensified in response to the cooling of the Southern Ocean at this time (Figure 2).

This cooling of the Southern Ocean reflected the progressive fragmentation of Gondwana by plate tectonic processes: each of the circum-Antarctic continents of India, Africa, Australia and South America progressively rifted off its respective northern margin of Antarctica and drifted away to the north, in turn progressively opening up the circum-Antarctic oceans. Once the last seaway had been opened (the Drake Passage, which fully opened to deep oceanic water throughflow in the late Paleogene (e.g., Livermore et al. 2005) or earliest Neogene (e.g., Schnitker 1980)), the Antarctic Circumpolar Current was established. This Antarctic Circumpolar Current, in effect, deflected away from the high southern latitudes, warm waters that had hitherto transported warmth from the tropics to those higher latitudes and had helped to maintain global climates that were more equable and less latitudinally differentiated (e.g., Schnitker 1980). Prior to the establishment of the Antarctic Circumpolar Current those tropical waters had maintained a milder climate in Antarctica (and that despite its persistently high latitude throughout the late Mesozoic and Cenozoic) - the widespread occurrence of temperate rainforest in Late Mesozoic Antarctica is ample evidence of that milder climate (e.g., Dettmann 1989).

The compartmentalisation of the oceans by the dispersal of continents led to a re-organisation of oceanic circulation, a 'knock-on' effect of which was the thermal isolation of Antarctica (Schnitker 1980), an effect that was ultimately felt around the globe with global cooling. The abrupt cooling at 33-34 Ma (Figure 2), which is now argued to be coeval with the Drake Passage opening to deep water throughflow (Livermore et al. 2005), coincided with the onset of Antarctic glaciation (Zachos et al. 2002), neatly demonstrating the link between plate tectonics and environmental change. This cooling of the Southern Ocean is widely implicated in progressive global aridification during the Neogene (e.g., Van Zinderen Bakker and Mercer (1986) for Africa; Hartley and Chong (2002) for southwestern South America (the Atacama); and, as we have seen, Bowler (1982) for Australia). Cooling oceans lead to less evaporation and hence aridity, but the reorganisation of ocean currents and their associated transfer of heat as a result of the reorganisation of the distribution of landmasses by plate tectonics is also important in this regard. Thus, final closure of the Panama seaway at 4.6 Ma (Haug and Tidemann, 1998) and closure of the Indonesian seaway at 5-3 Ma (Cane and Molnar, 2002) have both been implicated in changes in the global thermohaline circulation and consequent Northern Hemisphere glaciation and intensified global climate aridification (but note Maslin et al.'s (1998) argument that the timing of the closure of Panama indicates that that event was not implicated in triggering Northern Hemisphere glaciations). In the case of the Indonesian seaway, Cane and Molnar (2002) argued that northward movement of the Indo-Australian plate, and in particular northward displacement of New Guinea about $5 \mathrm{Ma}$, may have changed the 
Bishop, P. Plate tectonics etc in Matthews, J.A. et al. (editors). 2012. The SAGE

Handbook of Environmental Change. London, Sage; Volume 1, pages 363-383

flow of water to the Indian Ocean from warm South Pacific water to relatively cold North Pacific water. Sea surface temperatures in the Indian Ocean would therefore have fallen and rainfall declined over eastern Africa. Moreover, they suggested that these changes may have reduced the advection of heat from the tropics to higher latitudes, thereby reinforcing global cooling and the eventual growth of ice sheets.

Aridity, as we have seen, is also a function of at least four other factors, namely location in the subtropical high pressure belts, continentality, rain shadow, and cold offshore currents that suppress evaporation from the oceans adjacent to a landmass. Houston and Hartley (2003) have shown in relation to the Atacama Desert how these factors interact, and Figure 4 highlights clearly how global tectonics figures in the development of the Atacama Desert (although Bowler's (1982) arguments above (Figure 2) must be remembered, namely, that the stability of subtropical latitudinal position of South America that Houston and Hartley (2003) have invoked, based on palaeomagnetic data, as important for the development of the Atacama, cannot necessarily taken to mean that the subtropical high pressure belts have also remained stable in latitudinal location).

A significant element in the debate about the antiquity of the Atacama is the importance of the rainshadow effect in the aridification of the Atacama and the timing of Andean uplift. Hartley and Chong (2002) have argued that the timing of the major hyper-aridification of the Atacama, which they interpreted to have been late Pliocene, and the coincidence of that with aridification of the Sahara and the Namib deserts, means that the aridification was driven largely by global cooling and not by rainshadow effects from the Andes which began to be uplifted in the mid to late Miocene (Lamb and Davis 2003). Dunai et al. (2005) have argued that the aridification is earlier and can be related to the development of rainshadow in the lee of an uplifting Andes; Evenstar et al. (2009) also placed the onset of aridity in the mid Miocene. Whatever their differences between the interpretations of the timing of aridification in the Atacama, all agree that the rainshadow effect downwind of the Andes is important in that aridification.

As we have seen, the almost continuous global cooling since about $50 \mathrm{Ma}$ (Figure 2) is explained by the progressive breakup of Gondwanaland in the southern hemisphere and the compartmentalisation of oceans. One of the periods of most rapid cooling was at $34 \mathrm{Ma}$ and was associated with the sudden appearance of a large continental ice sheet in Antarctica, intensification of atmospheric and oceanic circulation, development and intensification of the polar front, and, as we have seen, widespread increased aridity (Zachos and Kump 2005). It was noted above that the abrupt cooling at $34 \mathrm{Ma}$, which may have occurred in less than $50 \mathrm{kyr}$ (Zachos et al. 1996), has been causally linked with the opening of the Drake passage, which permitted the establishment of the Circumpolar Current with all its 'knock-on' effects. It can be seen from Figure 2 that temperatures at the abrupt $34 \mathrm{Ma}$ cooling somewhat 'overshot' what can be taken as the new post-cooling-event 'equilibrium' temperature established by about $32 \mathrm{Ma}$. Zachos et al.(2005) have used relatively simple numerical modelling to show that the overshoot can be explained by large-scale biogeochemical feedbacks on the climate system as it adjusted to its new state. In particular, they tested for the influence of two important feedbacks that influence the concentration of atmospheric $\mathrm{CO}_{2}$, namely (i) the positive feedback of the rate of oceanic overturn, which controls primary production and the extraction of atmospheric $\mathrm{CO}_{2}$ as a result of carbon burial 
Bishop, P. Plate tectonics etc in Matthews, J.A. et al. (editors). 2012. The SAGE

Handbook of Environmental Change. London, Sage; Volume 1, pages 363-383

(thereby enhancing cooling), and (ii) the negative feedback resulting from cooling leading to a decrease in rates of weathering of continental silicate minerals, which is a major sink for atmospheric $\mathrm{CO}_{2}$, thereby leading to less cooling (because less atmospheric $\mathrm{CO}_{2}$ is being drawn down and so the atmosphere is not cooled as much as when greater amounts of $\mathrm{CO}_{2}$ are extracted from the atmosphere by mineral weathering). The latter process has been implicated in more complex ways in which plate convergence and uplift can influence environmental change, to which we now turn.

\section{Mountain uplift and the development of major climate systems}

One of the major advances of the last quarter of a century has been the recognition that the uplift of major mountain ranges, such as the Rockies and the Himalayas, could have led to global scale re-organisation of climate systems that go beyond the orogen-scale changes in climate on the uplifting mountain block itself and in immediately adjacent areas, which are the focus of the 'Surface Uplift' section above. Ruddiman et al. (1989) noted that Hermann Flohn had hypothesized in 1950 that the high topography of the Himalayas is a critical determinant of the strength of the south Asian summer monsoon and reported the testing of that generic notion in three linked papers (Ruddiman et al. 1989; Kutzbach et al. 1989; Ruddiman and Kutzbach 1989). In the context of changing climates, Kutzbach et al. (1989) summarised early attempts to explore the role of tectonics (mountain uplift and changing land-ocean distributions) in explaining past climates. The deep low pressure over the Tibetan plateau is a key element in driving the northern summer monsoon, the depth of that low pressure system reflecting the heating of the Tibetan plateau, which itself must be a function, at least in part, of the continentality of the Tibetan plateau (and hence its dryness and high temperatures unmoderated by an adjacent ocean). Equally, the strength of the outflow from the Asian landmass in the southern summer monsoon reflects the cold air and high pressure over the ice fields of the Himalayas (Ruddiman et al. 1989).

Numerical experiments with general atmospheric circulation models (GCMs) also indicate a second major way in which tectonics influence climate and potentially generate environmental change, namely, the manner in the northern hemisphere in which the elevated terrain of western North America and the Himalayas/Tibetan Plateau are important factors in the mean positions and amplitudes of planetary atmospheric standing waves. Thus, Ruddiman et al. (1986) suggested that uplift of western North America may have generated stronger southward meanders of such standing waves over east central North America and thereby promoted Pleistocene glaciation.

The early models, such as that of Kutzbach et al. (1989), have a coarse resolution, with only 20 model grid points covering the Tibetan Plateau and 10 the Colorado Plateau (Figure 5). Nonetheless, the results point to important responses to uplift, including changes in heating near the plateaux, as well as changes in the upper air circulation patterns and the distribution of sea level pressure. The seasonal heating and cooling of the Tibetan plateau that were noted above as major forcing factors for the northern hemisphere and southern hemisphere monsoons are generated by the Kutzbach et al. (1989) model with progressive uplift. Also simulated with uplift are large changes in vertical and horizontal atmospheric circulation, and precipitation, and it is particularly noteworthy that progressive uplift causes monsoon-like circulation to develop in response to the rise of the Colorado and Tibetan Plateaux. It is also notable 
Bishop, P. Plate tectonics etc in Matthews, J.A. et al. (editors). 2012. The SAGE

Handbook of Environmental Change. London, Sage; Volume 1, pages 363-383

that the magnitudes of these various changes are greatest for the Tibetan area, and that progressive uplift also leads to a more 'meandering' atmospheric circulation at middle atmospheric levels. As Ruddiman and Kutzbach (1989) concluded:

"The basic direction of most of these simulated responses to progressive uplift is borne out by changes found in the geologic record: winter cooling of North America, northern Europe, northern Asia, and the Arctic Ocean; summer drying of the North American west coast, the Eurasian interior, and the Mediterranean; winter drying of the North American northern plains and the interior of Asia; and changes over the North Atlantic Ocean conducive to increased formation of deep water. The modeled changes result from increased orographic diversion of westerly winds, from cyclonic and anticyclonic surface flow induced by summer heating and winter cooling of the uplifted plateaus, and from the intensification of vertical circulation cells in the atmosphere caused by exchanges of mass between the summer-heated (and winter-cooled) plateaus and the mid-latitude oceans."

(Ruddiman and Kutzbach 1989, p. 18409)

The increased meandering of the jet stream results in a cooler winter in northern Asia along with much of Europe, parts of the Arctic Ocean, and the mid-latitudes of east central North America. A stronger northerly flow associated with the changed jet stream explains these changes, some of which are notably distant from the uplifting plateaux. Conversely, Alaska, eastern Siberia and Greenland, become warmer in winter due to a stronger southerly air flow in the planetary wave. Changes in precipitation that are consistent with palaeoclimate proxy data were also simulated by Ruddiman and Kutzbach's (1989) numerical experiments, emphasising again the potentially farreaching influence of surface uplift in driving environmental change. They also noted that many of the Northern Hemisphere Neogene climate changes that are usually described as 'climatic deterioration' can be broadly accounted for in terms of the effects of the plateaux uplift that they simulated. In other words, that Northern Hemisphere uplift must be added to the changes in oceanic circulation noted above as a key driver of Neogene global cooling.

A large number of numerical simulations with GCMs have tended to confirm the influences of mountain uplift on Late Cenozoic regional and global climates, including the enhancement of Indian and southeastern Asian monsoons, and the cooling of the Northern Hemisphere (Ramstein et al. 1997). Ramstein et al. (1997) added a further dimension to such investigations by including realistic palaeogeography (i.e., the distribution of continents, reflecting plate motions). Their aim was to assess separately the effects both of the closure of the 'Paratethys' ocean that lay between the Indian and Asian landmasses and which was closed by the collision of India and Asia, and of the uplift of the Tibetan plateau. In other words, they married the two broad tectonic influences on environmental change, namely, those resulting from changes to the distribution and circulation of the oceans and those resulting from mountain uplift. Ramstein et al.'s (1997) modelling demonstrates that the 'Paratethys' ocean exerts a moderating influence on climate that is lost with closure of the ocean as India drifts northwards and approaches Asia (cf. Aitchison et al. 2007). The closure of Paratethys increases seasonality - after the ocean is closed, Central Asia summers are hotter and 
Bishop, P. Plate tectonics etc in Matthews, J.A. et al. (editors). 2012. The SAGE

Handbook of Environmental Change. London, Sage; Volume 1, pages 363-383

winters colder - and hence the pressure gradient across southern Asia is enhanced, as is the monsoonal circulation (Figure 6). In highlighting the important role of the Paratethys and its closure in driving environmental change, these results are different from those in the modelling of Kutzbach et al. (1989) and Ruddiman and Kutzbach (1989). Ramstein et al.'s (1997) modelling also highlights the importance for environmental change of the northward drift of India away from the inter-tropical convergence zone: the monsoon accounts for $<60 \%$ of rainfall in the middle part of India in the Oligocene, whereas in the Miocene, when India has drifted further north, the monsoon is responsible for nearly $80 \%$ rainfall in middle India. The modelling of Zhisheng et al. (2001) provides more detail on the evolution of climates with uplift of the Himalayas and the Tibetan plateau, as well as on the correspondence between a wide range of palaeoclimate proxies and their modelling results (Figure 7).

\section{Thinking differently about tectonics and climate change}

The foregoing highlights clearly how global tectonics are implicated in environmental change at the local, regional and hemispherical scales via the impacts of surface uplift and the spatial and temporal distributions of oceans and atmospheric circulation. The work of Zachos and Kump (2005) also shows that the carbon cycle is key to climate change and we now turn to that matter in relation to global tectonics and a major debate about Neogene climate change and mountain uplift. That debate has been summarised thus:

"[T]wo alternative hypotheses [exist] to explain the Late Cenozoic history of the planet: (1) the climate change is the direct or indirect result of tectonic uplift, or (2) the climate change has nothing to do with uplift, but has altered earth surface processes in such a way as to simulate widespread uplift."

(Hay et al. 2002, p. 746).

The first of these hypotheses, from Molnar and England (1990), builds on the work of Jeffreys (1931) and Wager (1937) more than half a century before and proposes that regional isostatic response to valley incision may lead to mountain peak uplift (Figure 8). Molnar and England's (1990) key insight was that climate change can drive tectonics and surface uplift: they argued that global cooling leads to an increase in glacial erosion, resulting in isostatic uplift of peaks (reflecting the concentration of erosion in valley bottoms and the relative lack of lowering [crustal removal] of peaks Figure 8). It is hypothesized that this uplift of the peaks leads to further cooling and accumulation of snow and ice on the peaks, further glacial erosion and denudational isostatic uplift of peaks, further glacial erosion, and so on. In short, Molnar and England (1990) argued that climate can drive rock uplift via denudational isostasy, which in turn leads to further climatic deterioration because the erosion driven by the ongoing cooling is concentrated in valley bottoms and is associated with denudational isostatic uplift, and hence cooling, of peaks.

Building on the work of Ruddiman and Kutzbach (1989), Raymo and Ruddiman (1992) proposed the opposite causal linkages in this famous 'chicken or egg' question as to whether climate can drive (or 'lead') rock uplift (tectonics). Raymo and Ruddiman (1992) thought that the various tectonic / plate tectonic explanations for climate change (see above) were insufficient and proposed that a critical further mechanism depended 
Bishop, P. Plate tectonics etc in Matthews, J.A. et al. (editors). 2012. The SAGE

Handbook of Environmental Change. London, Sage; Volume 1, pages 363-383

on the fact that rock uplift leads to mountain peak uplift, resulting in turn in an increases in glaciation and glacial mechanical erosion. That glacial erosion produces large quantities of fine-grained sediment composed of fresh minerals which are very weatherable. The chemical weathering of those grains is largely via reaction with atmospheric $\mathrm{CO}_{2}$, drawing $\mathrm{CO}_{2}$ out of the atmosphere and meaning that the planet cools in response to the decrease ion the atmospheric content of greenhouse gases. In short, Raymo and Ruddiman (1992) proposed that rock uplift leads to global cooling, glacial erosion and then further cooling via the drawdown of $\mathrm{CO}_{2}$ in the weathering of that glacial sediment.

Molnar and England's (1990) hypothesis faces several key problems in the fluvial domain, which they were not explicitly addressing, as well as in the glacial, which they were. The whole debate about climate change driving tectonics "hinges on the question of whether climate change can significantly increase topographic relief or, more precisely, increase the volume of 'missing mass' between summits and ridges" (Whipple et al. 1999, p. 39).

Physical and numerical modelling suggests that more erosive fluvial climates lead to relief reduction (not increase) (e.g., Bonnet and Crave 2003), but perhaps a more telling issue, that relates to both fluvial and glacial settings, is that limits to the mechanical strength of the lithosphere mean that mountain peaks cannot simply keep increasing in elevation, as the right-hand box of Figure 8 could be taken to be diagrammatically suggesting. Mountain peaks will fail by large, deep-seated, gravitydriven landslides in a process called tectonic denudation that prevents ongoing growth of mountain relief (e.g., Reinhardt et al., 2007). Moreover, in topographic steady-state settings that characterise areas of active rock uplift and high precipitation/river discharge, such as the Himalayas (Burbank et al. 1996), Taiwan (Dadson et al. 2003) and the Southern Alps (Adams 1985; Tippett and Hovius 2000), slope morphology and process are closely adjusted to rock strength: slopes stand at the limiting slope angle for the strength of the rock (see Bishop's (2007) fuller discussion of these issues). As rock is uplifted and rivers incise, slopes steepen and then fail, so as to maintain their equilibrium slope angle. Relief remains, in effect, constant (mountain peaks cannot grow in elevation relative to the adjacent valley bottoms). Simple geometry dictates that the only way in which relief from valley bottom to mountain peak can grow in such steadystate settings of constant slope angle is by a decrease in drainage density (that is by increased spacing of rivers - Whipple et al. 1999). In fact, in fluvial settings, increased erosiveness of climate is probably associated with increased precipitation which is likely to lead to an increase in drainage density (more runoff) which, via the argument from geometry, will lead to decreased relief. That conclusion is confirmed by Whipple et al.'s (1999) numerical modelling.

Brozovic et al. (1997) argued that a change to a more erosive glacial climate leads to a reduction in relief, and numerical modelling to assess the magnitude of mountain peak uplift as a result of localized valley incision suggests that there are limits to this effect (Gilchrist et al., 1994; Montgomery, 1994). Gilchrist et al. (1994), for example, showed that it seems unlikely that the volumes of the glacial valleys excavated in such major mountain belts as the Alps (i.e., the amounts of unloading due to erosion of valleys) are sufficient to generate the mountain peak altitudes envisaged by Molnar and England (1990). In a similar vein, Small and Anderson (1998) argued 
Bishop, P. Plate tectonics etc in Matthews, J.A. et al. (editors). 2012. The SAGE

Handbook of Environmental Change. London, Sage; Volume 1, pages 363-383

that valley excavation cold account for only limited plateau summit uplift in Laramide ranges in the western USA, particularly because of the flexural rigidity of the Laramide lithosphere (that rigidity meaning that the isostatic response to unloading by valley incision is horizontally distributed over length scales of the order of $\sim 10-100 \mathrm{~km}-$ Small and Anderson (1998)). In that case, valley incision would result in relatively subdued surface uplift of the plateau summits (or none at all, if the low 'background' rate of plateau lowering is taken into account), either way resulting in insufficient surface uplift of peaks to drive further climate change. The same authors argued that a large proportion of the surface uplift of the Sierra Nevada, also in the western US, could have been generated as an flexural isostatic response to valley erosion (unloading) within the Sierra Nevada itself and sedimentary loading in the Central Valley and flexural uplift of the adjacent Sierra Nevada (Small and Anderson 1995). Nonetheless, the amounts of surface uplift do not seem sufficient to generate major climate change.

Whipple et al.'s (1999) qualitative analysis of glacial settings identified a set of processes that increase relief (i.e., increase the 'missing mass' - cf. the quotation from Whipple et al. (1999) above) as well as a suite of processes that act to reduce relief. So, whether relief is increased in glacial settings (e.g., by glacial trough deepening) or decreased (as a result of glacial processes lowering summits) depends on the relative efficacy of these two sets of processes, but on balance it seems that relief increase in glacial settings is limited (as Small and Anderson (1995) had argued, as we have seen). Indeed, in glaciated areas a consistent picture is emerging of landscapes that have a concentration of elevations around the glacial equilibrium line altitude (ELA), which can be taken to be the elevation down to which intense glacial erosion operates (e.g., Mitchell and Montgomery 2006; Egholm et al. 2009). In other words, the so-called glacial 'buzz-saw' acts to lower summit elevations and therefore to decrease relief in glacial settings. It is difficult to sustain Molnar and England's (1990) argument that a change to a more erosive glacial regime will increase relief in mountain belts via enhanced isostatically-drive rock uplift in response to valley excavation, and hence drive further climate change.

\subsection{Volcanic eruptions}

Volcanic eruptions are driven by internal processes and large explosive eruptions introduce into the atmosphere large volumes of gases, including water vapour, $\mathrm{CO}_{2}$ and $\mathrm{SO}_{2}$, as well as finely particulate rock and glass fragments ('ash'). These changes to atmospheric composition modify radiation fluxes to the Earth (both inward and outward), which can in turn have impacts on land surface and ocean temperatures and hence lead to changes in local, regional and global weather and climate. Intuitively, the climatological effects of these various injections into the atmosphere can be opposed: the addition of $\mathrm{CO}_{2}$ would be expected to have a warming effect, whereas the addition of ash would be expected to block incoming solar radiation and hence to cool the Earth's surface (although such atmospheric particulates might also be expected to block outgoing long-wave radiation and hence to warm the Earth). The eruption of Krakatoa in Indonesia in 1883 demonstrated some of these effects in a general way: the year following Krakatoa was widely known as "the year without a summer", highlighting the cooling effect of the eruption cloud as it circled the globe. And the British artist, William Ashcroft, is renowned for his "Krakatoa sunsets" artworks, depicting the spectacular 
Bishop, P. Plate tectonics etc in Matthews, J.A. et al. (editors). 2012. The SAGE

Handbook of Environmental Change. London, Sage; Volume 1, pages 363-383

orange and red sunsets in London that were caused by Krakatoa's ejecta cloud; these artworks form the frontispiece for The Report of the Krakatoa Committee of the Royal Society (Simmons 1888).

Data and modelling of the effects of another volcanic event in the tropics, the 1991 eruption of Pinatubo, have provided considerable insight into the effects of volcanic eruptions on weather and climate. Mount Pinatubo volcano on Luzon Island in the Philippines erupted between June 12 and 16, 1991, resulting in the largest volcanic aerosol cloud in the stratosphere in the twentieth century, derived notably from the major eruption on June 15 (Stenchikov et al. 1998; Robock 2003). The total injection of $\mathrm{SO}_{2}$ into the stratosphere was up to about $20 \mathrm{Mt}$ (Robock 2003 and references therein), along with volcanic ash and other gases. The $\mathrm{SO}_{2}$ reacted to form an aerosol cloud of $\mathrm{H}_{2} \mathrm{SO}_{4}$ with complex effects on temperature (e.g., Stenchikov et al. 1998). In an unexpected spin-off from the data generated by the eruption, the effects of the Pinatubo eruption on atmospheric temperature and hence global atmospheric water vapour have been used to test the validity of current representations of the roles of enhanced and decreased water vapour in general circulation models of global weather and climate (which representations, incidentally, seem to be shown by the Pinatubo data to be successful - Soden et al. 2002).

The observed climatic effects of this particular eruption are more complex and more spatially variable than simple warming or cooling. Thus, substantial winter warming of northern hemisphere continents was observed in the two winters following the eruption, but was accompanied by enhanced cooling over the Middle East and Greenland in those winters as well as subtropical and tropical cooling (Robock 2002, 2003) (Figure 9). As Robock (2003) has noted, such spatial variability in weather response to the eruption had not been predicted, and numerical modelling has shown it to be a dynamical response to the radiative perturbation from the volcanic aerosols and ozone depletion from the eruption (e.g., Stenchikov et al. 1998, 2002). The combination of lower troposphere being warmed by the volcanic aerosols and an enhanced polar vortex driven by an increased equator-to-pole temperature gradient, generates a wave response in the tropospheric circulation, the increased amplitude of which brings warmer air to Asia, Europe and North America (Stenchikov et al. 1998). The environmental response to volcanic eruption is spatially and dynamically complex.

The environmental impacts of volcanic eruptions is also far-reaching in terms of linked effects. For example, the cooling over the Middle East caused by the Pinatubo eruption resulted in cooler sea surface temperatures in the Red Sea. That cooler water sank, leading to convective mixing of the full depth of the water column, leading in turn to enhanced nutrient supplies and blooms of algae and phytoplankton. These blooms smothered and killed coral in the Red Sea, thereby generating a decidedly unexpected outcome of the eruption of Pinatubo (Robock 2003). Grinsted et al. (2007) have noted further impacts on the marine domain of volcanic eruptions, namely, in terms of sealevel. Intuitively, it might be expected that global cooling associated with a volcanic eruption would result in thermal contraction of the ocean and hence a fall in relative sealevel. Such a fall (of $\sim 5 \mathrm{~mm}$ ) has been modelled but the observational evidence for such falls has been unconvincing (Grinsted et al. 2007). The global sea-level data base assembled by those authors comprises 830 time series of monthly mean relative sealevel world-wide, covering 150 years. They assessed the impacts on sea-level of the 
Bishop, P. Plate tectonics etc in Matthews, J.A. et al. (editors). 2012. The SAGE

Handbook of Environmental Change. London, Sage; Volume 1, pages 363-383

nine largest historical volcanic eruptions, which produced atmospheric aerosol loading of at least $10 \%$ of that of Pinatubo. Interestingly, the five largest eruptions were tropical, which are the only type of eruption to have impacts in both northern and southern hemispheres, and the average effect of these eruptions is clearly registered in relative sea-level (Figure 10).

Grinsted et al. (2007) noted that the explanation of the trends highlighted in Figure 10, namely a rise in sea-level in the year following the eruption followed by a more extended fall in sea-level in subsequent years and then recovery, is not immediately evident, especially for the initial rise. That rise is unexpected if, as has been argued, the eruption products shield the Earth and the oceans cool (and hence contract). The authors hypothesized that the initial sea-level rise reflects a decrease in evaporation from the cooled ocean (hence more water remaining in the ocean and a sea-level rise) and that the subsequent fall in sea-level arises from the ensuing decrease in precipitation over land and correspondingly reduced river discharge to the oceans. Both effects (the initial rise in sea-level and its subsequent fall) reflect the reduced evaporation from a cooled ocean.

The environmental effects of volcanic eruptions that have been discussed so far last for in the order of five years, and hence could be thought of as comparable to the environmental changes associated with the El Niño / La Niña cycle (Grinsted et al. 2007). Recent work has shown, however, that the environmental effects of volcanic eruptions may last for decades. Gleckler et al. (2006) have argued that the effects of the 1883 eruption of Krakatoa lasted for decades after the eruption, as a result of the penetration to great depths of the water cooled after Krakatoa. That these effects are to be expected follows logically from the observations of cooling and sinking of the Red Sea surface waters after Pinatubo (see above). A key point made by Gleckler et al. (2006) is that the persistent effect of Krakatoa has counteracted a major part of the warming and expansion of the oceans to be expeccted as a result of anthropogenically emhanced greenhouse-gases.

It might be expected that such perturbations to vertical water motions might have more widespread and profound impacts on the great global-scale oceanic circulation driven by the thermohaline properties of oceanic waters, especially in relation to the strength of the North Atlantic Drift. That speculation, which highlights the way in which the ocean may retain a 'memory' of major volcanic eruptions via the transmission of sea surface cooling to ocean depths, is an issue that would benefit from future research.

\section{Conclusions}

Long-term environmental changes that are driven by Earth-internal forcing factors the set the context for the environmental changes driven by the external factors that are more usually considered in the context of environmental change, such as astronomical forcing and now anthropogenic changes to atmospheric composition. Thus, such endogenically-driven environmental change needs to be understood before the more usual sorts of environmental changes and their associated forcing factors are considered. One of the most interesting debates of the last 15 years has been the extent to which tectonics (surface uplift) can drive environmental change and/or vice versa (the so-called climate and tectonics chicken-and-egg problem). This seems to be being resolved in favour of the conclusion that climate can drive tectonics (via rock uplift 
Bishop, P. Plate tectonics etc in Matthews, J.A. et al. (editors). 2012. The SAGE

Handbook of Environmental Change. London, Sage; Volume 1, pages 363-383

driven by denudational isostasy) but that the magnitude of such effects is not large and essentially insufficient to drive further climate change via the uplift and further cooling of mountain peaks that are being eroded at lower rates than the average rate across the landscape. Intriguingly, the related effect in steady-state landscapes, namely rapid rock uplift (exhumation) in areas of rapid river incision (e.g., the tectonic aneurysm of Zeitler et al. (2001)), is associated with very rapid rock uplift as a result of denudational isostasy. In that case, however, there is no net surface uplift (and hence no rock upliftdriven climate change) because the landscape is in steady state and being eroded across the whole landscape at the rate at which rock is being uplifted; see the discussion of these matters elsewhere (Bishop 2007).

Numerical modelling has clearly pointed to the ways in which surface uplift and ocean closure associated with plate convergence may lead to environmental change, leading in turn to important insights as to the development of the Asian monsoon. A second major plate tectonic change that has been implicated as a major driver of environmental change is the opening of the last seaway in the Southern Ocean (the Drake Passage), with the resultant cooling of that ocean and the glaciation of Antarctica. That cooling led in turn to cooling and aridification globally, in areas as widespread as Australia, South America and East Africa. To the author's knowledge, Bowler's (1980) qualitative suggestion ('thought experiment') that the continental and oceanic reorganisation associated with the opening of the last Gondwanan seaway led to the development of the circum-polar current that was then associated with major restructuring of the atmospheric circulation systems remains to be assessed in detail. Bowler suggested that that reorganisation led to the northward compression of the climate zones and the overtaking of Australia from the south by the mid-latitude high pressure systems. Such a major tectonically driven reorganisation of global climate systems will repay serious investigation, not least because the subseqent global cooling is central to some of the major environmental changes that the Earth has experienced during the Neogene.

\section{References}

Adams J 1985 Large-scale tectonic geomorphology of the Southern Alps, New Zealand In Morisawa M Hack J T edsTectonic Geomorphology Allen and Unwin: London, 105-128.

Aitchison J C Ali J R Davis A M 2007 When and where did India and Asia collide? Journal of Geophysical Research 112 B05423, doi:10.1029/2006JB004706

Bishop P 2007 Long-term landscape evolution: Linking tectonics and surface processes Earth Surface Processes and Landforms 32 329-365, doi:10.1002/esp.1493

Bonnet S Crave A 2003 Landscape response to climate change: insights from experimental modeling and implications for tectonic versus climatic uplift of topography Geology 31 123-126

Bowler J M 1982 Aridity in the Tertiary and Quaternary of Australia in Barker W R Greenslade P J M eds Evolution of the flora and fauna of arid Australia Peacock Publications, Adelaide 35-46

Brozovic N Burbank D Meigs A 1997 Climatic limits on landscape development in the Northwestern Himalaya. Science 276 571-574 
Bishop, P. Plate tectonics etc in Matthews, J.A. et al. (editors). 2012. The SAGE Handbook of Environmental Change. London, Sage; Volume 1, pages 363-383

Burbank D W Anderson R S 2001 Tectonic Geomorphology Malden MA, Blackwell

Cane M A Molnar P 2002 Closing of the Indonesian seaway as a precursor to East African aridification around 3-4 million years ago Nature 411 157-162.

Dadson S J Hovius N Chen H Dade W B Hsieh M-L Willett S D Hu J-C Horng M-J Chen M-C Stark C Lague D Lin J-C 2003 Links between erosion, runoff variability and seismicity in the Taiwan orogen Nature 426 648-651.

Dalziel I 1997 Neoproterozoic-Paleozoic geography and tectonics: Review, hypothesis, environmental speculation Geological Society of America Bulletin 109 16-42, doi:10.1130/0016-7606(1997)109<0016:ONPGAT>2.3.CO;2

Dettmann M E 1989 Antarctica: Cretaceous cradle of austral temperate rainforests? Geological Society London Special Publications 47 89-105, doi:10.1144/GSL.SP.1989.047.01.08

Dunai T J Lopez G A G Juez-Larre J 2005 Oligocene-Miocene age of aridity in the Atacama Desert revealed by exposure dating of erosionsensitive landforms Geology 33 321-324, doi:10.1130/G21184.1

Egholm D L Nielsen S B Pedersen V K Lesemann J-E 2009 Glacial effects limiting mountain height Nature 460 884-887, doi:10.1038/nature08263

Evenstar L A Hartley A J Stuart F M Mather A E Rice C M Chong G 2009 Multiphase development of the Atacama Planation Surface recorded by cosmogenic ${ }^{3} \mathrm{He}$ exposure ages: Implications for uplift and Cenozoic climate change in western South America Geology 37 27-30, doi:10.1130/G25437A.1

Fujioka T Chappell J 2010 History of Australian aridity - chronology in the evolution of arid landscapes in Bishop P Pillans B eds Australian Landscapes. Geological Society of London Special Publication. In press.

Gilchrist A R Summerfield M A Cockburn H A P 1994 Landscape dissection, isostatic uplift, and the morphologic development of orogens Geology 22 963-966

Gleckler P J Wigley T M L Santer B D Gregory J M AchutaRao K Taylor K E 2006 Volcanoes and climate: Krakatoa's signature persists in the ocean Nature 439675 , doi:10.1038/439675a

Gregory-Wodzicki K M 2000 Uplift history of the Central and Northern Andes: A review Geological Society of America Bulletin 112 1091-1105

Grinsted A Moore J C Jevrejeva S 2007 Observational evidence for volcanic impact on sea level and the global water cycle Proceedings of the National Academy of Sciences 104 19730-19734, doi:10.1073/pnas.0705825104

Hartley A J 2003 Andean uplift and climate change Journal of the Geological Society, London 160 7-10

Hartley A J Chong G 2002 A late Pliocene age for the Atacama Desert: Implications for the desertification of western South America Geology 30 43-46

Haug G H Tidemann R 1998 Effect of the formation of the Isthmus of Panama on Atlantic Ocean thermohaline circulation Nature 393 673-676

Hay W W Soeding E DeConto R M Wold C N 2002 The Late Cenozoic uplift - climate change paradox International Journal of Earth Sciences 91 746-774, doi:10.1007/s00531-002-0263-1

Houston J Hartley A J 2003 The central Andean west-slope rainshadow and its potential contribution to the origin of hyper-aridity in the Atacama Desert International Journal of Climatology 23 1453-1464 
Bishop, P. Plate tectonics etc in Matthews, J.A. et al. (editors). 2012. The SAGE Handbook of Environmental Change. London, Sage; Volume 1, pages 363-383

Jeffreys H 1931 On the mechanics of mountains Geological Magazine 68 435-442 Jolley D W 1997 Palaeosurface palynofloras of the Skye lava field and the age of the British Tertiary volcanic province in Widdowson M (ed.) Palaeosurfaces: recognition, reconstruction and palaeoenvironmental interpretation Geological Society London Special Publication 120 67-94, doi:10.1144/GSL.SP.1997.120.01.06

Kirchner I Stenchikov G Graf H-F Robock A Antuna J 1999 Climate model simulation of winter warming and summer cooling following the 1991 Mount Pinatubo volcanic eruption Journal of Geophysical Research 104 19,039-19,055

Knesel K M Cohen B E Vasconcelos P M Thiede D S 2008 Rapid change in drift of the Australian plate records collision with Ontong Java plateau Nature 454 doi:10.1038/nature07138

Kutzbach J E Guetter P J Ruddiman W F Prell W L 1989 Sensitivity of climate to late Cenozoic uplift in southern Asia and the American west: Numerical experiments Journal of Geophysical Research 94 18393-18407

Lamb S Davis P 2003 Cenozoic climate change as a possible cause for the rise of the Andes Nature 425 792-797, doi:10.1038/nature02049

Lin J-C 2000 Morphotectonic evolution of Taiwan in Summerfield M A ed. Geomorphology and Global Tectonics John Wiley, Chichester 135-146

Livermore R Nankivell A Eagles G Morris P 2005 Paleogene opening of Drake Passage Earth and Planetary Science Letters 236 459- 470, doi:10.1016/j.epsl.2005.03.027

Maslin M A Li X S Loutre M-F Berger A 1998 The contribution of orbital forcing to the progressive intensification of Northern Hemisphere glaciation Quaternary Science Reviews 17 411-426

Martin H A 2006 Cenozoic climatic change and the development of the arid vegetation in Australia Journal of Arid Environments 66 533-563

McGowran B Holdgate G R Li Q Gallagher S J 2004 Cenozoic stratigraphic succession in southeastern Australia Australian Journal of Earth Sciences 51 459-496

Mitchell S G Montgomery D R 2006 Influence of a glacial buzzsaw on the height and morphology of the Cascade Range in central Washington State, USA. Quaternary Research 65 96-107

Molnar P England P 1990 Late Cenozoic uplift of mountain ranges and global climate change: chicken or egg? Nature 346 29-34

Montgomery D R 1994 Valley incision and the uplift of mountain peaks. Journal of Geophysical Research 99 13,913-13,921

Prell W L Kutzbach J E 1992 Sensitivity of the Indian monsoon to forcing parameters and implications for its evolution Nature 360 647-652, doi:10.1038/360647a0

Ramstein G. Fluteau F Besse J Joussaume S 1997 Effect of orogeny, plate motion and land-sea distribution on Eurasian climate change over the past 30 million years Nature 386788 - 795, doi:10.1038/386788a0

Raymo M E Ruddiman W F 1992 Tectonic forcing of late Cenozoic climate. Nature 359 $117-122$

Reinhardt L J Dempster T J Shroder J F Persano C 2007 Tectonic denudation and topographic development in the Spanish Sierra Nevada Tectonics 26 TC3001, doi:10.1029/2006TC001954

Robock A 2003 Introduction: Mount Pinatubo as a test of climate feedback mechanisms in Robock A Oppenheimer C eds Volcanism and the Earth's 
Bishop, P. Plate tectonics etc in Matthews, J.A. et al. (editors). 2012. The SAGE

Handbook of Environmental Change. London, Sage; Volume 1, pages 363-383

Atmosphere Geophysical Monograph 139, American Geophysical Union Washington DC, 1-8

Ruddiman W F Kutzbach J E 1989 Forcing of Late Cenozoic Northern Hemisphere climate by plateau uplift in southern Asia and the American west Journal of Geophysical Research 94 18409-18427

Ruddiman W F Prell W L Raymo M E 1989 Late Cenozoic uplift in southern Asia and the American west: Rationale for general circulation modeling experiments Journal of Geophysical Research 94 18379-18391

Ruddiman W F Raymo M Mclntyre A 1986 Matuyama 41,000 year cycles: North Atlantic Ocean and northern hemisphere ice sheets Earth and Planetary Science Letters 80 117-129

Schnitker D 1980 Global paleoceanography and its deep water linkage to the Antartcic glaciation Earth-Science Reviews 16 1-20

Simmons G J (ed.) 1888 The eruption of Krakatoa and subsequent phenomena: Report of the Krakatoa Committee of the Royal Society Royal Society, London

Small E E Anderson R S 1995 Geomorphically driven Late Cenozoic rock uplift in the Sierra Nevada, California Science 270 277-280

Small E E Anderson R S 1998 Pleistocene relief production in Laramide mountain ranges, western United States Geology 26 123-126

Soden B J Wetherald R T Stenchikov G L Robock A 2002 Global cooling after the eruption of Mount Pinatubo: A test of climate feedback by water vapor Science 296 727-730

Stenchikov G L Kirchner I Robock A Graf H-F Antuna J C Grainger R G Lambert A Thomason L 1998 Radiative Forcing from the 1991 Mount Pinatubo volcanic eruption Journal of Geophysical Research 103 (D12) 13837-13857

Stenchikov G Robock A Ramaswamy Vschwarzkopf M D Hamilton K Ramachandran S 2002 Arctic Oscillation response to the 1991 Mount Pinatubo eruption: Effects of volcanic aerosols and ozone depletion Journal of Geophysical Research 107 (D24) 4803, doi:10.1029/2002JD002090

Summerfield M A ed 2000 Geomorphology and Global Tectonics John Wiley, Chichester

Tippett J M Hovius N 2000 Geodynamic processes in the Southern Alps, New Zealand in Summerfield M A ed. Geomorphology and Global Tectonics John Wiley, Chichester 109-134

Van Zinderen Bakker E Mercer J H 1986 Major late Cainozoic climatic events and palaeoenvironmental changes in Africa viewed I a worldwide context Palaeogeography, Palaeoclimatology, Palaeoecology 56 217-235

Veevers J J Powell C M Roots S R 1991 Review of seafloor spreading around Australia. I. Synthesis of the patterns of spreading Australian Journal of Earth Sciences 38 373-389

Wager R L 1937 The Arun River drainage pattern and the rise of the Himalaya Geographical Journal 89 239-250

Weissel J K Hayes D E Herron E M 1977 Plate tectonics synthesis: The displacements between Australia, New Zealand, and Antarctica since the Late Cretaceous Marine Geology 25 231-277 
Bishop, P. Plate tectonics etc in Matthews, J.A. et al. (editors). 2012. The SAGE

Handbook of Environmental Change. London, Sage; Volume 1, pages 363-383

Whipple K X 2009 The influence of climate on the tectonic evolution of mountain belts Nature Geosciences 2 97-104, doi:

Whipple K X Kirby E Brocklehurst S H 1999 Geomorphic limits to climate-induced increases in topographic relief Nature $40139-43$

Willett S D Brandon M T 2002 On steady states in mountain belts Geology 30 175-178

Willett S D Slingerland R Hovius N 2001 Uplift, shortening, and steady state topography in active mountain belts American Journal of Science 301 455-485

Zachos J C Kump L R 2005 Carbon cycle feedbacks and the initiation of Antarctic glaciation in the earliest Oligocene Global and Planetary Change 47 51-66

Zachos J Pagani M Sloan L Thomas E Billups K 2001. Trends, rhythms, and aberrations in global climate $65 \mathrm{Ma}$ to present Science 292 686-693

Zachos JC Quinn T M Salamy K A 1996 High-resolution (104 years) deep-sea foraminiferal stable isotope records of the Eocene-Oligocene climate transition Paleoceanography 11 251-266

Zeitler P K Meltzer A S Koons P O Craw D Hallet B Chamberlain C P Kidd W S F Park S K Seeber L Bishop M Shroder J 2001 Erosion, Himalayan geodynamics, and the geomorphology of metamorphism. GSA Today 11 4-9

Zhisheng A Kutzbach J E Prell W L Porter S C 2001 Evolution of Asian monsoons and phased uplift of the Himalaya-Tibetan plateau since Late Miocene times Nature 411 62-66, doi:10.1038/35075035 
Bishop, P. Plate tectonics etc in Matthews, J.A. et al. (editors). 2012. The SAGE

Handbook of Environmental Change. London, Sage; Volume 1, pages 363-383

A. Frontal Accretion

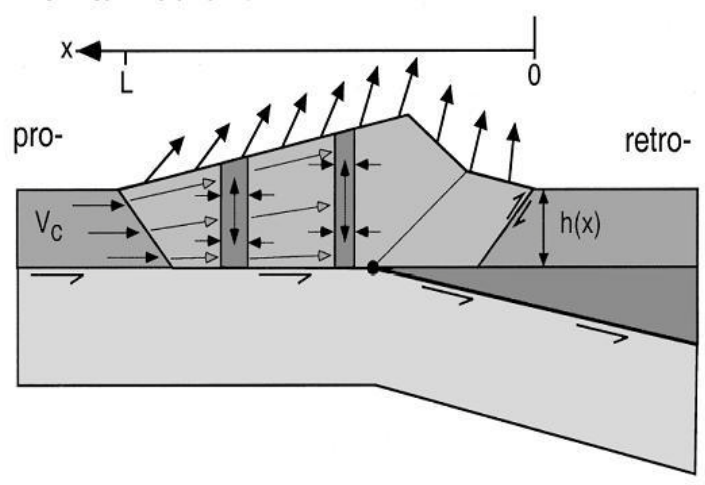

B. Underplating

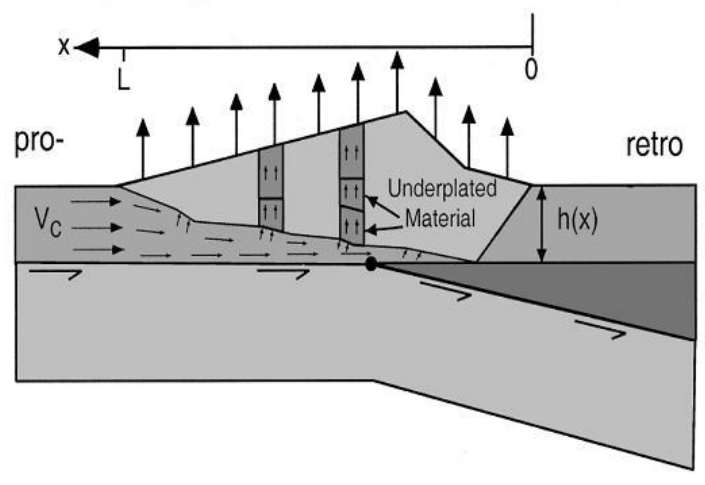

Figure 1. Willett et al.'s (2001) conceptual models for rock uplift at plate convergence zones. In the case of frontal accretion (upper), material is scraped off the subducting plate coming from the left. That material is compressed horizontally by the convergence and grows vertically, with that shear being accommodated by upward movement of surface as the crustal column moves horizontally. In the lower case ('Underplating'), material is added to the base of crust by the convergence motion, thickening the crust and leading to vertical movement of rock. 
Bishop, P. Plate tectonics etc in Matthews, J.A. et al. (editors). 2012. The SAGE

Handbook of Environmental Change. London, Sage; Volume 1, pages 363-383

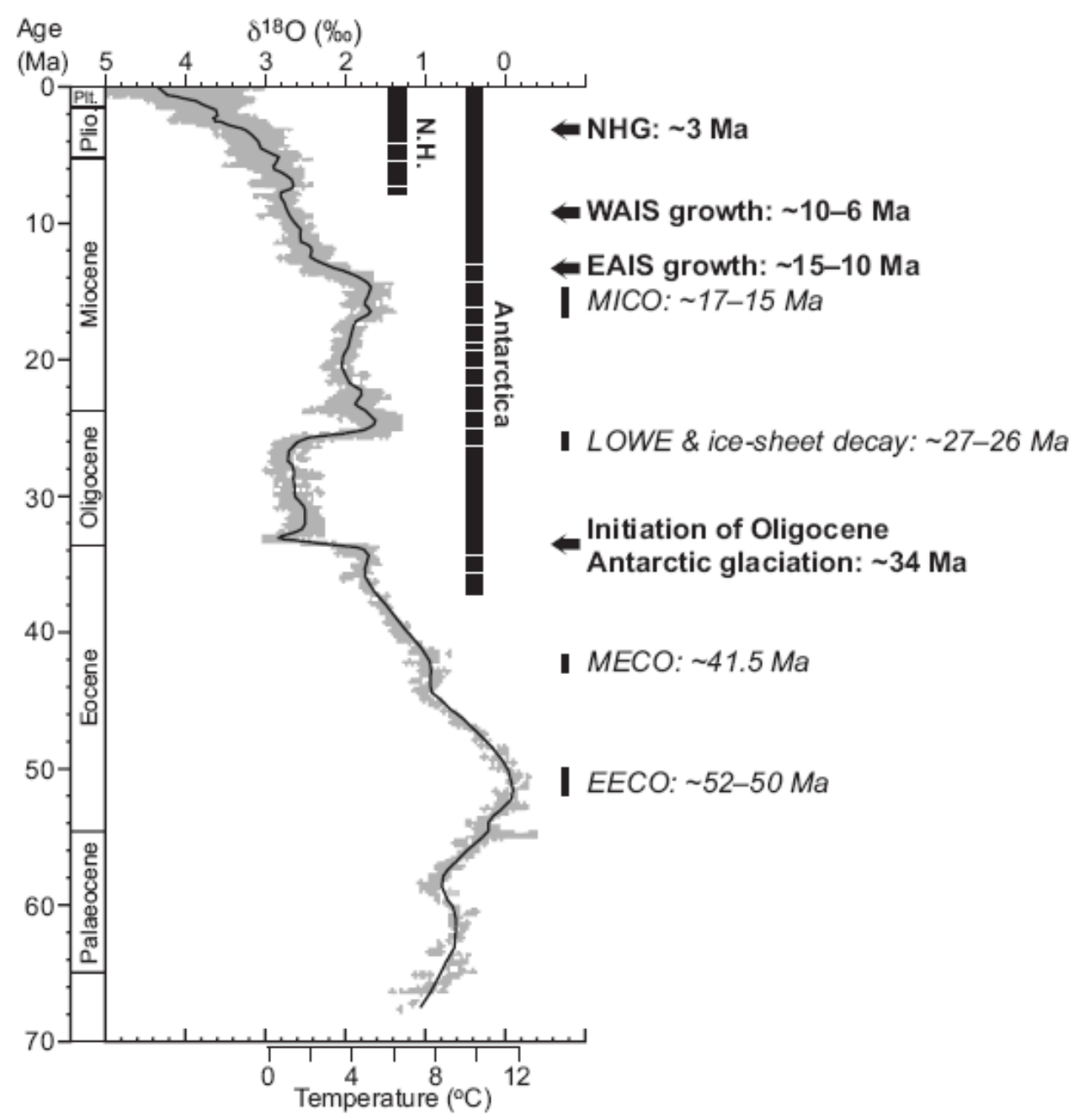

Figure 2. Global deep-sea oxygen isotope record, based on data from over 40 DSDP and ODP sites, with major climatic events including ice-sheet evolution during the Cenozoic (after Zachos et al. (2001) and Fujioka and Chappell (2010)). Smoothedmean benthic $\delta 180$ values are shown; the temperature scale at the bottom, showing deep-sea temperature for an ocean free of ice-sheets, is strictly only applicable to the time prior to the initiation of Antarctic glaciation at c.34 Ma. Vertical thick bars represent qualitatively the ice volume in Antarctica and Northern Hemisphere (N.H.) (dashed = partial or ephemeral ice volume $(\leq 50 \%$ of present $)$; full bar $=$ full scale and permanent ice sheet $(>50 \%$ of present)). Arrow + text $=$ cooling event; thin bar + text $=$ warming event (after Zachos et al. 2001; McGowran et al. 2004). NHG = Northern Hemisphere Glaciation; WAIS = West Antarctic Ice Sheet; EAIS = East Antarctic Ice Sheet; MICO = Miocene Climatic Optimum; LOWE = Late Oligocene Warming Event; MECO = Middle Eocene Climatic Optimum; EECO = Early Eocene Climatic Optimum. 

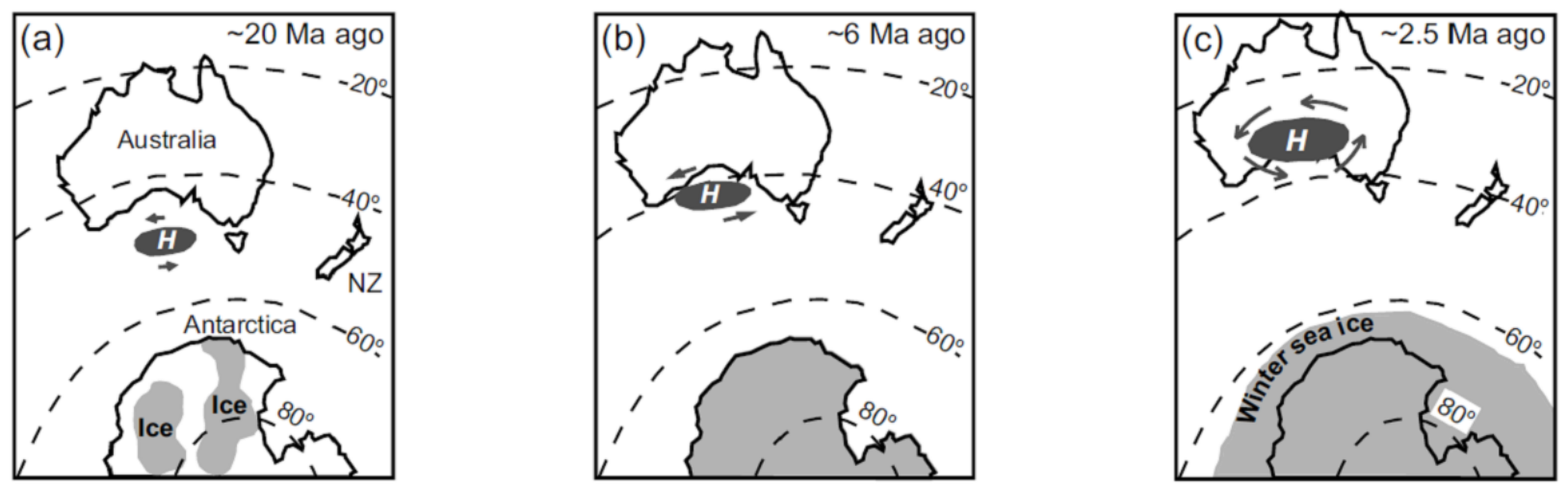

Figure 3. Bowler's (1982) hypothesis that the sub-tropical high pressure system ('H') 'overtook' Australia from the south during the Neogene, reflecting the fact that the impact of the cooling of the Southern Hemisphere led ultimately to the glaciation of Antarctica. The impact of that cooling and glaciation on the surrounding seas extended northwards more rapidly than Australia's northward movement by plate tectonic processes. Atmospheric circulation was compressed to the north as the Antarctic cooled, and the temperature gradient from equator to pole and latitudinal zonation of climate were increased. Bowler (1982) hypothesized that a related effect of this northward migration/compression of climate zones was an increase in the intensity of circulation (and hence windspeed) around the sub-tropical high pressure systems menaing that increasing aridity was accompanied by windier conditions suitable for dune formation. Fujioka and Chappell (2010) provide more data on the history of aridity in Australia. 
Bishop, P. Plate tectonics etc in Matthews, J.A. et al. (editors). 2012. The SAGE

Handbook of Environmental Change. London, Sage; Volume 1, pages 363-383

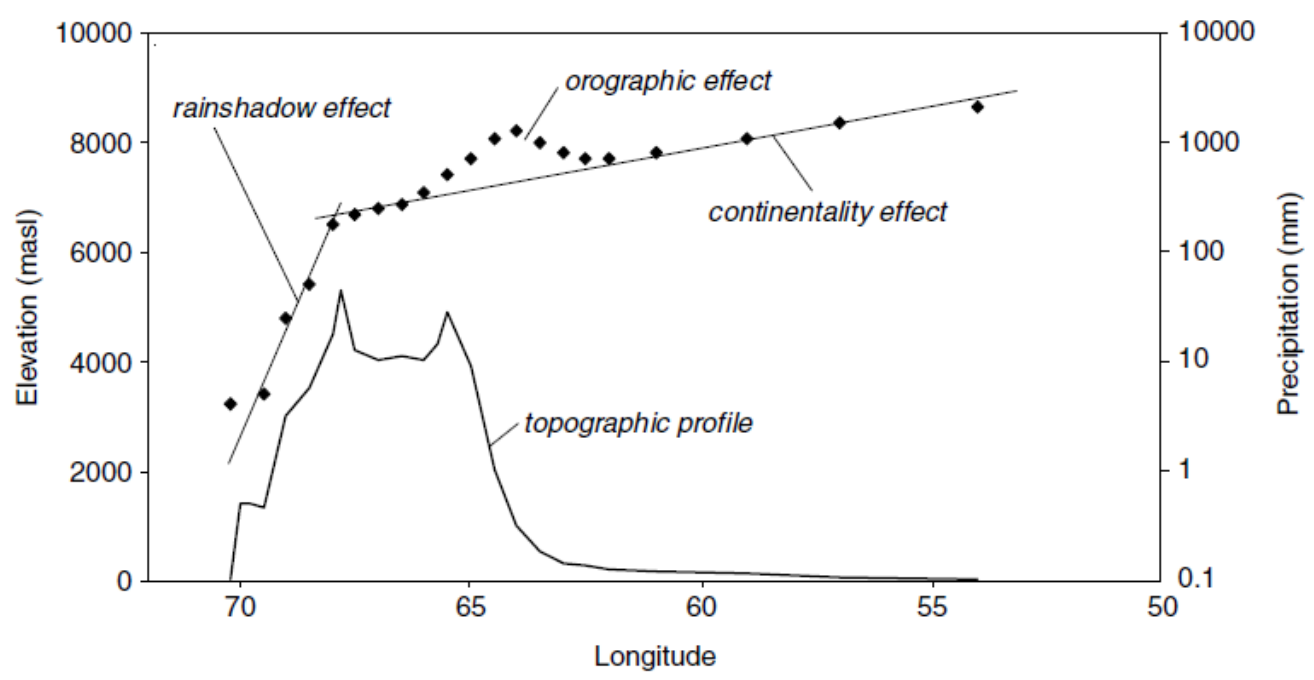

Figure 4. Generalized southwest-to-northeast section of elevation and mean annual precipitation across South America (from Iquique to Belem, across the Andes) illustrating continentality and orographic effects, and highlighting how the aridity of the Atacama desert on South America's western seaboard reflects the rainshadow effect of the Andes and continentality, both effects in relation to the dominant source of rainfall from the east. The combination of (i) the steep decline in rainfall in the rainshadow of the Andes, from a relatively low starting value of $\sim 100 \mathrm{~mm}$ p.a. that itself reflects the continentality effect, (ii) the cold offshore current and (iii) the sub-tropical location is clearly expressed in the hyper-aridity of the Atacama. The rainshadow is a function of the plate tectonics-driven uplift of the Andes and continentality is a function of the size of the continent, which reflects in turn the rifting processes that dismembered Gondwanaland. The latitude of South America and the establishing of the offshore current also reflect plate tectonics. (Houston and Hartley (2003) have noted in the caption to this figure, their Figure 4, that the data points are not station data but arbitrary points from contoured precipitation maps.) 
Bishop, P. Plate tectonics etc in Matthews, J.A. et al. (editors). 2012. The SAGE

Handbook of Environmontal Channo I nndnn Cana. Volume 1, pages 363-383
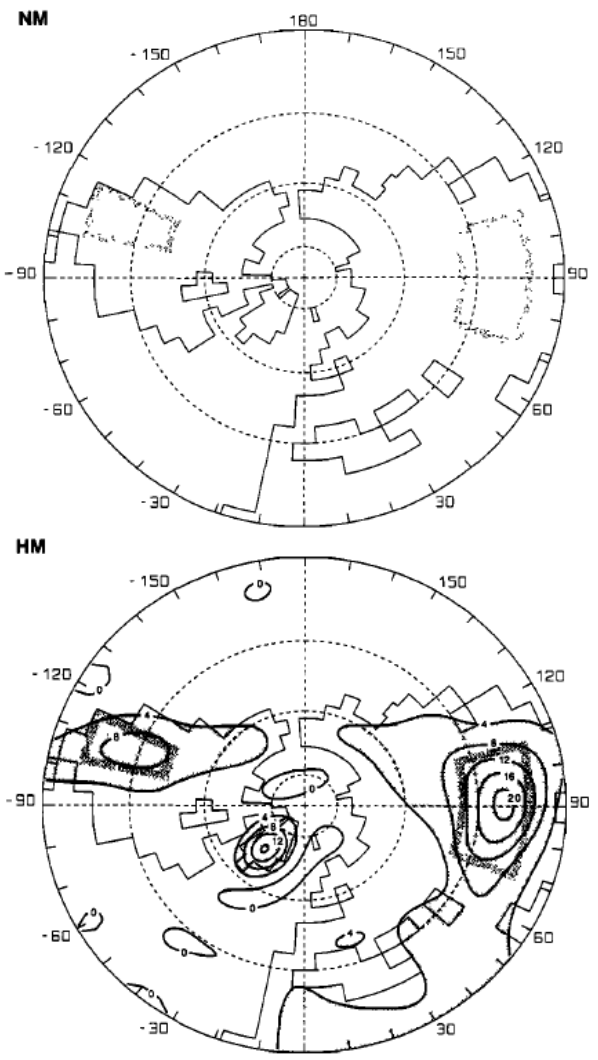

M

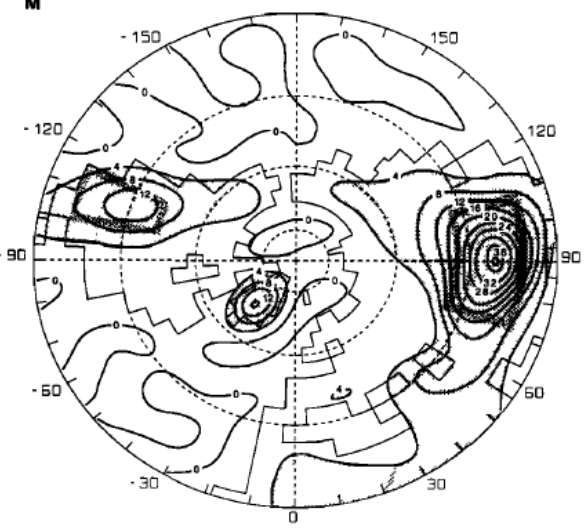

Figure 5. Topography (elevations in hundreds of metres; $\mathrm{Cl}=400 \mathrm{~m}$ ) of the Kutzbach et al. (1989) model for their numerical experiments of the no-mountains (NM), halfmountains (HM), and mountains (M) cases. Note the coarseness of the grid size $\left(4.4^{\circ}\right.$ latitude by $7^{\circ}$ longitude). The three experiments (NM, HM and M) are taken to correspond to three eras in the geological past when those proportions of uplift of the western North American and southern Asian mountains (namely no mountains, halfheight mountains and the present mountain heights) existed. The HM case is said to approximate the late Miocene-early Pliocene case (10 - $3 \mathrm{Ma}$ ) and the $\mathrm{M}$ case gives the results of the GCM with modern conditions. 
Bishop, P. Plate tectonics etc in Matthews, J.A. et al. (editors). 2012. The SAGE

Handbook of Environmental Change. London, Sage; Volume 1, pages 363-383

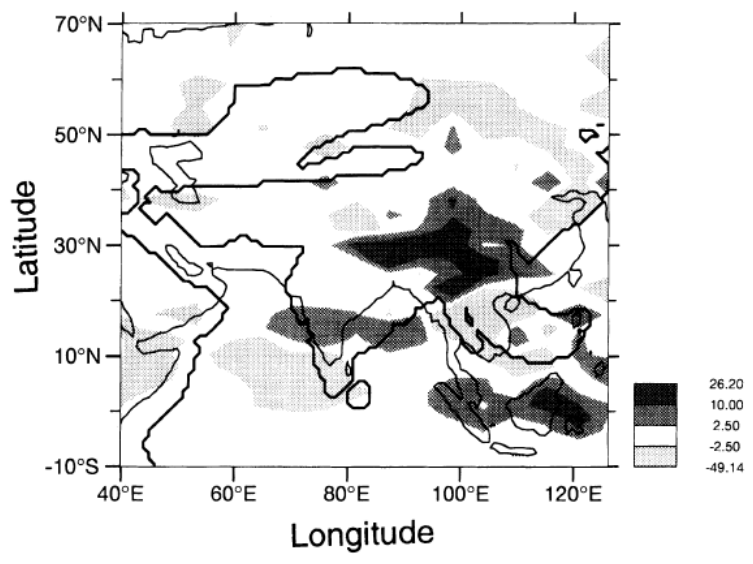

Figure 6. Summary of the results of Ramstein et al.'s (1997) modelling giving the mean precipitation differences (shading scale in $\mathrm{mm}$ per day) between the present and the Early Oligocene for their summer GCM. The thick line represents the Early Oligocene coastline (note the Paratethys ocean in the northwest sector) and the thin line is the modern coast. Note how the closure of Paratethys and northward drift of India are associated with enhanced monsoonal precipitation in India and SE Asia. 
Bishop, P. Plate tectonics etc in Matthews, J.A. et al. (editors). 2012. The SAGE

Handbook of Environmental Change. London, Sage; Volume 1, pages 363-383
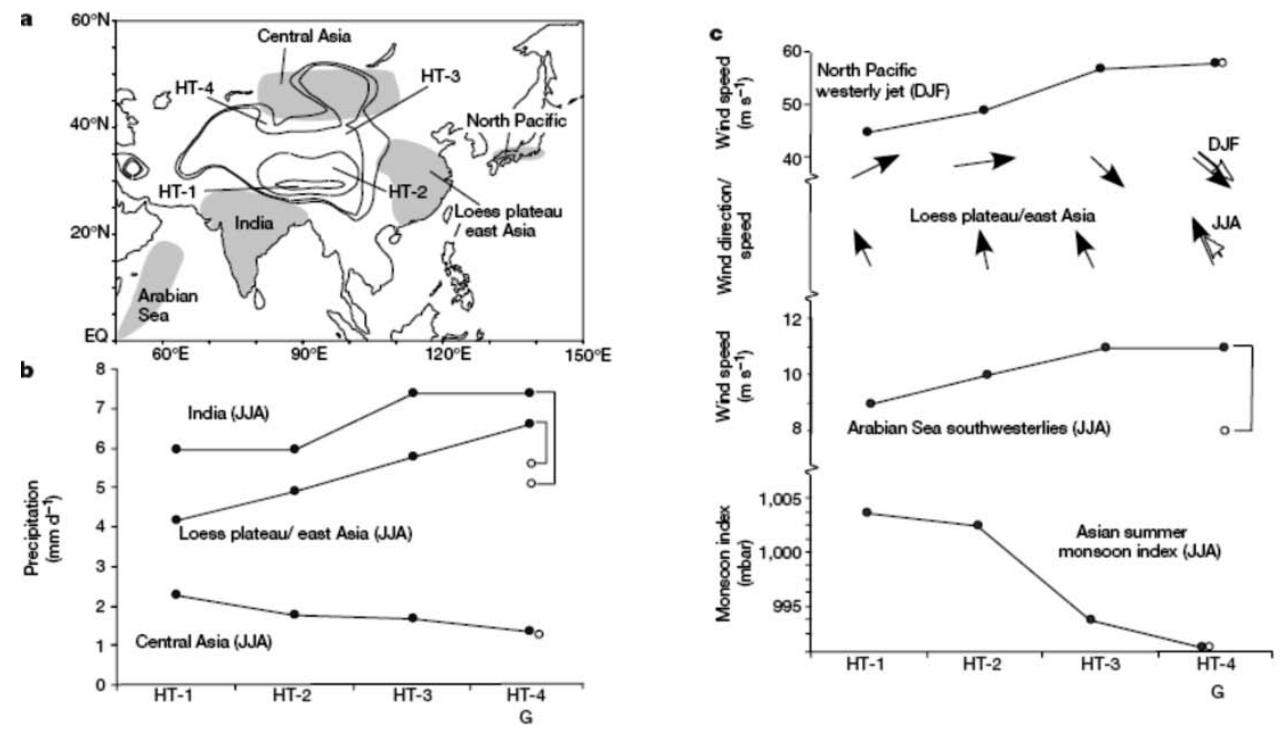

Figure 7. A. Areas (in grey) the climate indices of which are used in the numerical modelling of the effects of uplift (which are indicated by the approximate boundaries of the generalized topography stages with elevations higher than 1,000 m outlined by the thin 'form' lines: model HT-1, small elevated region, with maximum elevation less than 1,700 m; model HT-2, Himalaya and Tibetan plateau of limited north-south and eastwest extent with maximum elevation 2,700 m; model HT-3, Himalaya and Tibetan plateau considerably extended to the north and west with maximum elevation $5,700 \mathrm{~m}$; and model HT-4, modern, with extension of the plateau along the eastern and northern margins and maximum elevation $5,700 \mathrm{~m}$. The elevations and topography in the climate model are smoothed to reflect the spatial resolution of the climate model, and are substantially lower than the elevations observed or estimated from palaeo-elevation proxies.

B. Summer (June-July-August: JJA) precipitation for India, the Loess Plateau/east Asia, and central Asia, for four simulations (HT-1 to HT-4) with progressive increase in mountain-plateau elevation, and one simulation $(G)$ with glacial-age modifications to $\mathrm{HT}-4$ (lowered atmospheric $\mathrm{CO}_{2}$ concentration, enlarged Northern Hemisphere ice sheets, lowered sea surface temperatures). The climate values for $\mathrm{G}$ are indicated with an open circle connected to the climate value for HT-4 by a thin vertical line.

C. Wind and circulation indices for the four elevation stages and the one glacial stage: westerly jet-stream winds in winter (December-January-February: DJF) for the western North Pacific, wind direction and relative speed (length of arrow) in JJA and DJF for the Loess plateau/east Asia region (the open arrows refer to stage $G$ ), southwesterly winds in the Arabian Sea in JJA, and an index of the intensity of the large continent-scale Asian summer monsoon, JJA, given by the sea-level pressure at the centre of the monsoon circulation (Source: Zhisheng et al. (2001) Fig. 3, p.64, with this caption largely taken from the caption to that figure). 
Bishop, P. Plate tectonics etc in Matthews, J.A. et al. (editors). 2012. The SAGE

Handbook of Environmental Change. London, Sage; Volume 1, pages 363-383

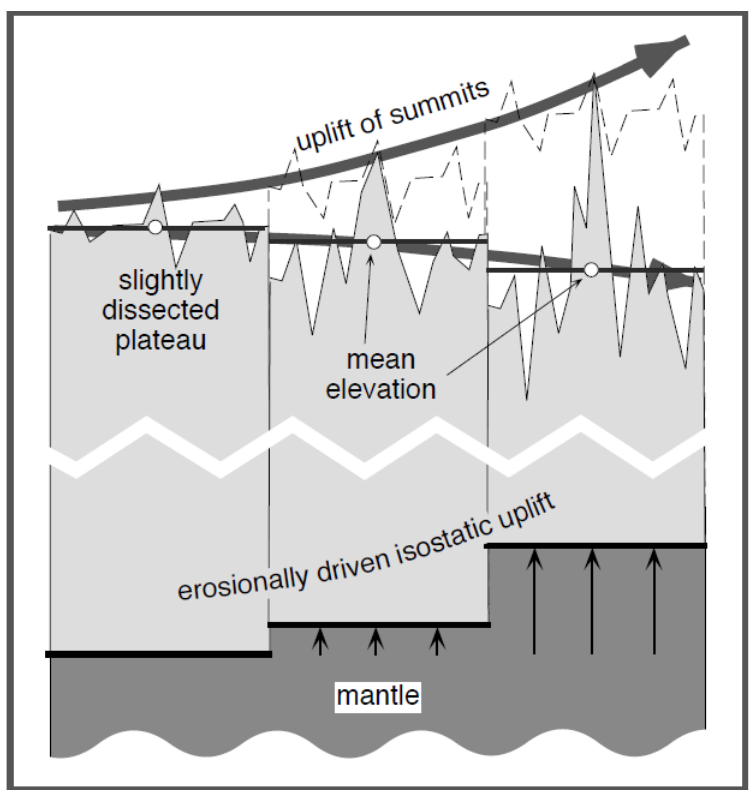

Figure 8. Concentration of erosional unloading of the lithosphere in valleys and limited erosion of the adjacent peaks can lead to uplift of those peaks. Note that any surface erosion must lead to an overall decline in mean surface elevation of an area in isostatic equilibrium and free to respond isostatically to the erosional unloading. In the case illustrated here, the mechanical strength of the lithosphere means that localised unloading leads to more regional isostatic response and so the peaks may rise as the lithosphere floats up regionally by $80 \%$ of the regional unloading, which in this case is concentrated in the valleys (Source: Burbank and Anderson 2001, Figure 10.26) 
Bishop, P. Plate tectonics etc in Matthews, J.A. et al. (editors). 2012. The SAGE

Handbook of Environmental Change. London, Sage; Volume 1, pages 363-383

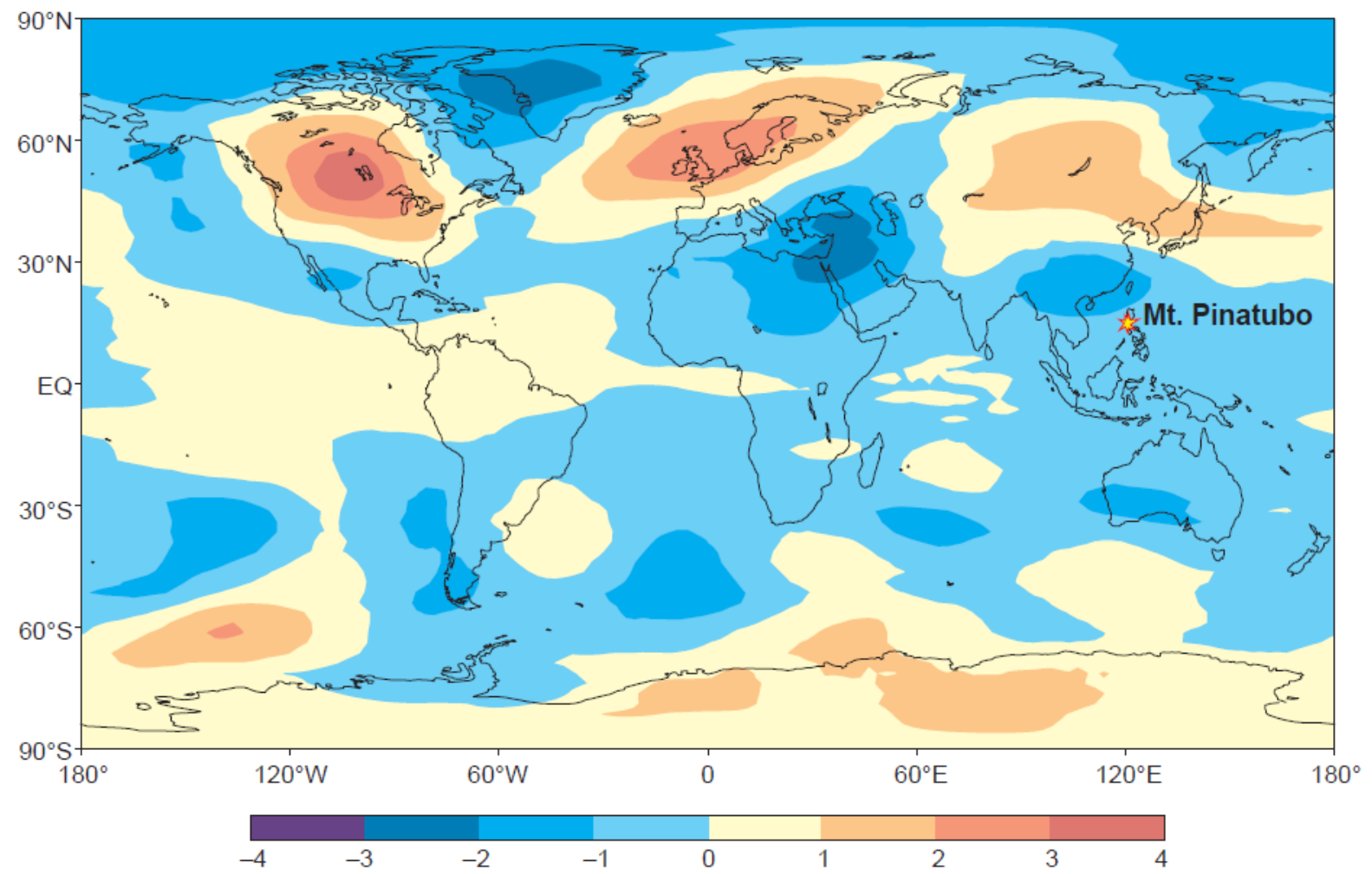

Figure 9. Lower tropospheric temperatures for the northern winter (December 1991 to February 1992) after the 1991 Pinatubo eruption, plotted as departures $\left({ }^{\circ} \mathrm{C}\right)$ from the mean temperatures for the nonvolcanic period of 1984-1990. Robock (2003) noted that the pattern of temperatures 'anomalies' typifies that after large tropical eruptions: warming over North America, Europe, and Siberia; cooling over Alaska, Greenland, the Middle East, and China. (Source: Robock 2003, Figure) 
Bishop, P. Plate tectonics etc in Matthews, J.A. et al. (editors). 2012. The SAGE

Handbook of Environmental Change. London, Sage; Volume 1, pages 363-383

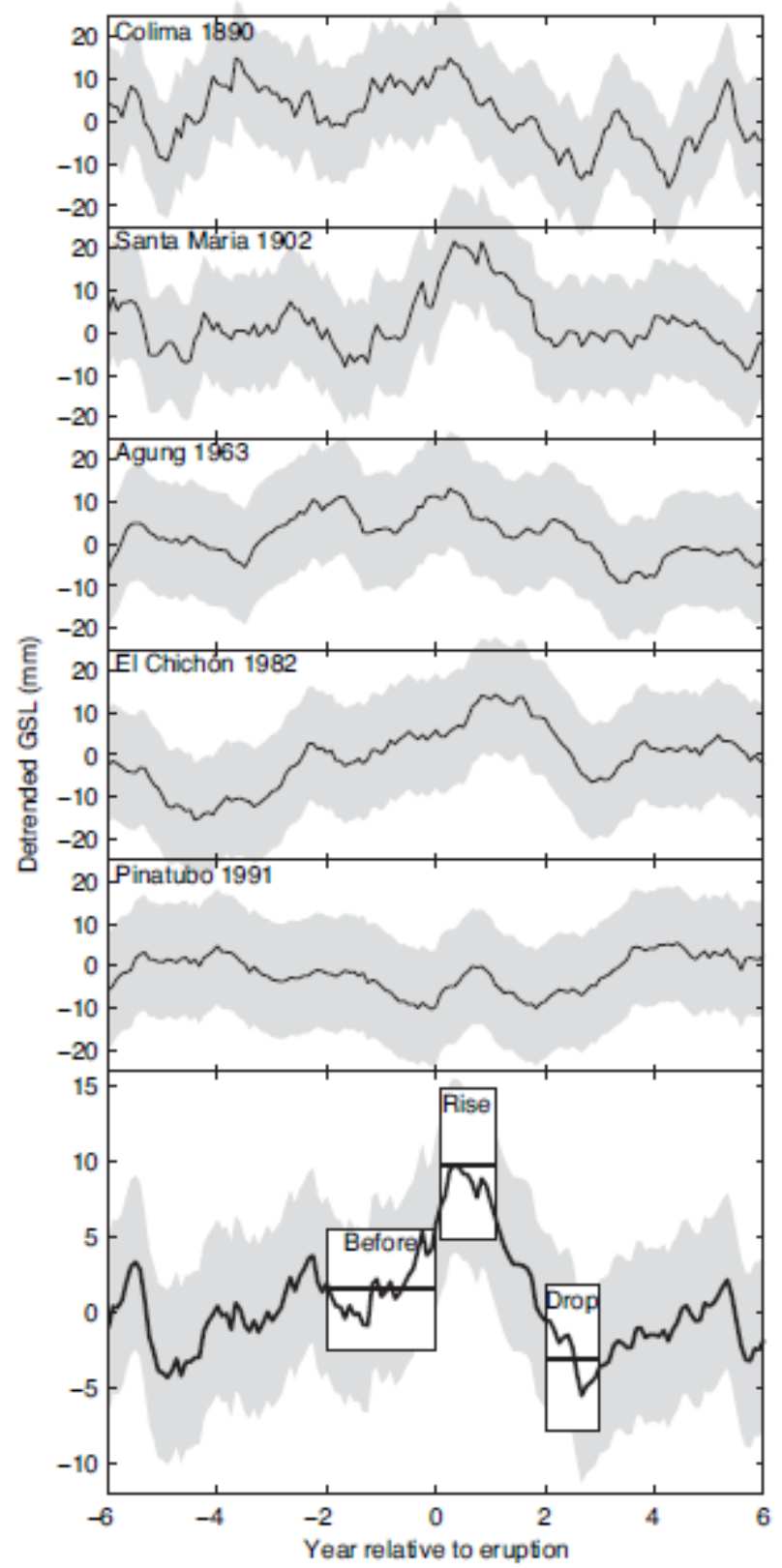

Figure 10. The top five curves give average sea level for the 12 years surrounding the five major volcanic eruptions studied by Grinsted et al. (2007). The solid black curves are the detrended global sea-level from tide gauge records (with $95 \%$ confidence interval in grey). The bottom curve shows the average sea-level response from the five curves. The centre line in each box is the the median sea-level for that period ("Before" the eruption, a sea-level "Rise" in the year following the eruption, followed by a "Drop" in the following two to four years). The top and bottom edges of each box show the $95 \%$ confidence interval of the median. The sea-level generally recovers to its pre-eruption levels about five years after the eruption. 